\title{
Soft Law in the French public Administration
}

\author{
Claude BARREIX \\ Université de Paris-Est Créteil AEI IPAG (Public Administration Institute) France \\ Partner in LIPHA laboratory
}

\begin{abstract}
France is traditionally the country of hard law and is known for having voted or decided and implemented a lot of laws and regulations often setting up complex and excessive standards in various fields related to economic, social and even personal life of its citizens. In principle, the French seem opposed to relationships ruled by soft law as contracts or agreements. The purpose of this article is to try to show that even if their culture leads them to mistrust soft law, the French have been for a long time using this legal instrument, particularly in public administration. The movement has been developed since the 1990's mainly concerning framework contracts with the unions, internal contracts and charters. A development of soft law, now approved by the 'Conseil d'Etat' (the French highest level of the administrative jurisdiction) would participate to simplify and diminish excessive standards and contribute to add value to the image of France as a modern state.
\end{abstract}

Keywords: soft law, hard law, standards, public service, contract, agreement, charter

\section{INTRODUCTION}

Traditionally hard law prevails in the French institutions. It is patent that the French society is characterized by abundant regulations on every subject: economic, social, societal.., with a large interference of government in the relationships between the individuals on various matters belonging to all sorts of fields: economic, social, ethic, even private life sometimes... and this seems well accepted until now, by a majority of citizens.

Estimations say that not less than 400, 000 laws, decrees, and other forms of regulations are ruling the life of the French people. Within a very codified and universal law, soft law seems to encounter difficulties to find its place. However in the last decades, France tends to organize relationships inside the companies and public administrations through some contracts, agreements, charters, between companies or public bodies and customers, service users, or between employers and unions. A lot of these contracts are non-binding commitments, just having a moral value and possible disagreements cannot come under a court. Actually soft law more and more tends to belong to the French legal landscape: its flexibility seems to correspond better with the running of a modern state.

The 'Conseil d'Etat' (Council of state) itself which is the French highest level of the administrative jurisdiction, has confirmed in 2013 the inclusion of soft law in the French legal instruments after having formerly qualified it as 'flabby law' in 2006. The high council qualifies now as soft law all legal texts that meet three conditions:

○ They have to modify or guide the behavior of their recipients by encouraging, to the extent possible, their support;

- They do not create their own rights or obligations for their recipients;

○ they have, by their content and method of production, a degree of formality and structure that resembles the rules of law.' 
FRANCE IS CHARACTERIZED BY ABUNDANT LEGISLATION AND REGULATIONS TO BE APPLIED ALL OVER ITS TERRITORY

When we compare France with other developed countries, we notice that these codes deal with every activity and often are very huge. For instance, the French labour code contains 3400 pages and 4000 articles. The same code in Switzerland has only 200 articles as in other developed countries where most of rights and obligations linking employers and employees are registered in contracts. The situation of the United Kingdom where there is no labour code, job contracts being mainly ruled by the Common Law, is often quoted on this side of the Channel, even if the French generally are very reserved on this practice.

Similarly the French Highway code contains 421 pages while the English one has only 138 (horse riding included!).

In French schools, numerous headmasters and headmistresses complain that they annually receive thousands of pages of official instructions by mail and more and more often by e-mail, from the ministry of education, its local representatives and sometimes other ministries and public bodies. Due to the weight of their charge these officials confess that, most of the time, they cannot read the whole of them, limiting their reading to major documents and only considering the headlines and the subject of the rest.

Sometimes law inflation is the consequence of news stories. So in 2007, as a consequence of several accidents with vicious dogs- some of them tragic-, six bills were presented before the parliament and one of them passed in 2008 followed during 2008 and 2009 by no less than 4 decrees to apply its provisions.

Closer to us in 2011, a decree and a ministerial order were published, carefully describing what the children meals must be composed of in the school canteens and it has been said that no less than 50 senior managers worked to elaborate these instructions. Classic advices are given: if bread and water may be given 'unlimited', salt and sauces must have a restrictive use.

Moreover, the texts go further giving a precise description of the food to be served to the children according to their age: different portions of meat, pizzas, sausages, desserts, with permitted variations of plus or minus ten percent, and how many vitamins and proteins they may contain. Common sense would have led to ask an official dietetic agency to give general recommendations to be implemented by local actors in the schools, avoiding the burden of official text writing.

The impact of regulation on competitiveness seems even more worrying: the World Economic Forum (WEFORUM), an independent international non-profit organization, is committed to improving the state of the world through public-private cooperation. It measures how burdensome for business is among others compliance with governmental requirements (e.g. permits, regulations, reporting...), with its consequences on competitiveness. In this rating, France occupies the 121st rank out of 144 surveyed countries.

It can be useful to compare this situation with that of a few advanced or emerging countries concerning business compliance with governmental requirements. The table on the next page contains data extracted from the WEFORUM report concerning 2014-2015.

If we compare European countries, France and traditional hard law countries stand at the last ranks while northern countries as United Kingdom for instance, stand in the first half of the ranking. These positions are considered by the economists, as the case may be, as either a 
handicap or an asset in the rough global economic competition the different nations are nowadays involved in.

\begin{tabular}{|l|c|}
\hline COUNTRIES & RANKS \\
\hline QATAR & 1 \\
\hline FINLAND & 7 \\
\hline CHINA & 19 \\
\hline IRELAND & 22 \\
\hline UNITED KINGDOM & 37 \\
\hline CANADA & 39 \\
\hline GERMANY & 55 \\
\hline USA & 82 \\
\hline FRANCE & 121 \\
\hline SPAIN & 123 \\
\hline GREECE & 136 \\
\hline ITALY & 142 \\
\hline
\end{tabular}

If we compare European countries, France and traditional hard law countries stand at the last ranks while northern countries as United Kingdom for instance, stand in the first half of the ranking. These positions are considered by the economists, as the case may be, as either a handicap or an asset in the rough global economic competition the different nations are nowadays involved in.

If we try to explain why the life of the French is so depending on such numerous and universal rules, we have to consider that this phenomenon is historical, traditional. France has centralized governance and the "equality principle" is a major founding of the "République". For the average French citizen it is difficult to admit that all over the territory, the law would not be enforced the same way, and be adapted to local constraints. This is illustrated by a permanent resistance to decentralization often considered as the door open to breaking the equality principle of which the central government must remain the best protector.

Moreover, France has adopted the 'precautionary principle' which is now engraved in ${ }^{2}$ the Constitution and that leads the government to respond to a large demand of safety measures concerning various fields: health, environment, building, work...

This situation can be a source of difficulties as it is abundantly developed in a report published in 2013 and written by Alain Lambert and Jean-Claude Boulard, at the end of a mission ordered by the prime minister, about how to fight against standards inflation.

This report recalls a lot of difficult situations where many legal standards break down the good running of citizens' everyday life and generate useless public expenditures and the authors prescribe drastic reduction of standards.

The case of a 500 inhabitant town, which has acquired a riding mower with a rotating beacon, is developed. In this small town the council employee has to cross the road with his machine on a few tens meters to move from a green place to another, but his mower has not legally the right to do that, even if it is duly insured. So as 'the law is the law', and as national laws must be applied everywhere in the country, the only solution for the council is to buy a mini tractor at last four times more costly, just to get the right to run from time to time on the road as it has got the required registration card, plates and indicators. To fix this type of problems, the report proposes to authorize modulation of the law to take account of local needs. More generally the authors ask public authorities to set up standards more through contracts than law or all other sort of regulations. 
The predominance of hard law in the French institutions often combined with standards inflation, could let think that soft law is absent in the legal landscape in this country. In reality even if they have to respect laws and regulations, standards often are produced out of them. Contracts and agreements are regularly endorsed and have been for instance belonging for a long time to the French citizens' everyday work life. That is true in the private sector where a lot of agreements inside the companies are ruling the relations between employers and employees, particularly in the frame of the 'comités d'entreprise' (work councils), composed of the manager, the workers and the unions' representatives who debate on subjects concerning current running of the firm (finance, working times, security and social concerns...) but also about its future. In the Public service, which this study focus on, soft law has been developed for a long time but have been taking a new shape since the 1990's with the 'Renouveau du service public' movement (Public service renewal) initiated by prime minister Michel Rocard ${ }^{1}$.

\section{Traditional forms:}

\section{SOFT LAW IN THE PUBLIC SERVICE IS MAKING PROGRESS}

It has to be noticed that in the public service soft law belongs to ordinary running of administrations. They use it as a vector of hierarchic instructions: in ministries, local authorities, and other public bodies, chief executives or directors issue circulars, memorandums to help the civil servants implementing official laws and regulations. These instructions are locally forwarded until the last level of hierarchy. For instance, the ministry of education sends a circular to the 'recteurs' (regional chief education officers) in order to supervise the implementation a new pedagogic reform set up by a law and decrees, and these will write a memorandum to be sent to the school headmasters in charge of implementing the reform.

Memorandums have always be used to set up internal rules to permit common running of public services; they contain provisions linked to opening times to public for the services, working time for the staff, various processes concerning the running of services as mail office, data office....or collective rules dealing with human resources (staff appraisal, wages, promotions, permanent training...) Nowadays, these instructions are communicated to the staff through various tools : notice boards but also, intranet, individual e mails..

\section{Modern forms of soft law in the Public service}

Since 1989 modernization of the Public service introduced by the 'circulaire Rocard' and completed by other instructions in 1995 and 1998 has been accelerating the implementation of soft law through new forms. The main three of them are developed here: framework agreements with the unions, internal contracts and charters:

\section{Framework contracts with the unions}

Dialogue between the government and representatives of the unions has been a tradition from the end of the Second World War. So the general statute of civil servants released in 1946 was the result of an intense negotiation which was translated in a classic law voted by the Parliament. Before the 1990's agreements belonging to soft law were rather rare but two important ones took place in 1968: first of all the 'Oudinot ${ }^{2}$ statement concerning civil servants' wages' and mainly the agreement about civil servants' careers signed after 'Masselin report $^{\prime 3}$ in 1969 which really marked the introduction of the notion of contract in the Public

\footnotetext{
${ }^{1}$ Michel Rocard had been the French prime minister from 1988 to 1991

2 Oudinot is the name of the Parisian street where the contract was signed

3 Pierre Masselin bélongue to the 'Cour des Comptes' (Public audit)
} 
service. Since 1989 and the 'circulaire Rocard' a lot of agreements have been periodically signed concerning general subjects mainly concerning human resource management: wages, permanent training, social dialogue, welfare benefits..., some of them end later losing their 'soft law 'characteristic when they were translated into hard law. That was the case for two agreements signed in 2006 about permanent training and welfare benefits the provisions of which were included in a law in 2007.

The last agreement signed on October $22^{\text {nd }} 2014$ by the minister of civil service and eight civil servants' union's concerns psycho-social risks. The signatories of this agreement established 9 general principles:

1) Avoiding risks;

2) Evaluating the risks which cannot be avoided;

3) Combating the risk at source;

4) Adapting the work to the agent, especially concerning the design of the work station;

5) Considering the changes in technology;

6) Replacing what is dangerous with what is not or less dangerous;

7) Defining a plan of prevention in a coherent work organization, working conditions, social relationships and the influence of environment factors including risks related to moral;

8) Taking collective protection measures giving them priority over measure for individual protection ;

9) Giving appropriate instructions to the workers.

All these measures include an assessment plan entrusted to a committee which is assigned of controlling the implementing contained in the agreement.

Even if these agreements are legally non biding, public authorities must be sincere when they promise to develop or promote any action because when the moment of assessment comes, they have to justify the results of their commitment and may lose unions' confidence and compromise possible new agreements.

Internal Contracts :

Modernization has led the government to increase the responsibility of managers on every step of the hierarchy in the aim to improve efficiency of the services and optimize public spending. New responsibilities were so delegated to local government authorities and public bodies mainly concerning fund management and human resource management.

This movement changed the relations between central and local government services and implied a new deal in order to lead public policies. Central authorities started defining main objectives and delegating financial and human means to local authorities that had to manage them and report their results.

This change is hence concretized by the conclusion of contracts between central and local authorities for one year or more. These agreements include an assessment process the results of which may have consequences on future allocations of means. However they belong to soft law and potential conflicts are not subject to be arbitrated by an administrative court.

Two examples can illustrate these contracts concerning universities 'contrat quiquennal' and 
other agencies or public bodies 'contrat d'objectifs et de performances':

French universities are linked with the ministry of higher education by a 'contrat quiquennal' respecting both national orientations and the strategy defined by each public body. From the 1990's these contracts have been signed every four years (and now five). The ministry commits financing a program of actions defined by each university that commits to reach the objectives contained in the program in respect with national directions. The contract project is based on a collective reflection in order to carry out a comprehensive project for the university associating all members of the university community: executive committee, professors and other teachers, students, managers and administrative staff, external leading figures members of the board. Then the project is negotiated with the ministry of higher education. Several subjects may be contained in these contracts, for instance dealing with promotion of new teachings and diplomas, development of research programs, development of partnerships with foreign universities, building of specialized premises as language laboratories, actions aiming to improve students' everyday life in the universities.

An example can be given concerning the quadrennial contract concluded for the period 20092012 by the University of Paris-Est Créteil (UPEC), containing three major objectives:

1. Linking training and research in visible multidisciplinary fields;

2. Continuing pooling policy with universities and other higher education bodies in Paris-Est Créteil area and developing scientific and territorial partnerships;

3. Galvanizing the management of the university under its strategic challenges.

UPEC received an annual 1.5 million euro allowance from the ministry of higher education. All the general objectives are declined in more operational common or specific objectives with indicators of performance to measure their achievements. For instance 'Success rate in bachelor's degree in three years' was one of the indicators which measured the achievement of a common objective to assess performance in teaching field; 'evolution of own revenues generated (out of public allowances)' was an objective which measured the achievement of a UPEC specific objective to develop apprenticeship, permanent training and research enhancement.

In 2013, more than $60 \%$ agencies or other public bodies had concluded a 'contrat d'objectifs et de performances' (contracts of objectives and performances) with the ministries that control their activity. These contracts allow clarifying the contribution of the operator to the objectives of public policy and monitor results achieved. This contract is a part of the management dialogue between the operator and the ministry; it is a contractual document that sets the strategic direction of the operator for a period (mainly 3 years). It contains operational objectives defined by the operator in accordance with the ministry directions the achievement of which has to be measured by limited number of indicators.

The 'contrat d'objectifs et de performances' signed for 2013-2016 between the ministries of ecology and agriculture with the IGN (National Geographic Institute) is a relevant example that can be given. Its structure is the following one:

Description of the context : missions of the IGN, assessment of the former contract, new events or constraints in the running of the public body, and ministerial priorities too;

General objectives defined for the period:

1. Create and promote knowledge, skills and innovation; 
2. Organize distribution and sharing of multi thematic data; create and promote knowledge skills and innovation;

3. Draw an established description of the territory;

4. Provide necessary services to use multi thematic sharing data; provide services to increase the use of data;

5. Provide service for the ministry of defense;

6. Develop strategy, driving the implementation of directions and ensure the support functions. These objectives are declined in operational objectives with one or several indicators to measure their achievement. For instance the operational objective 'ensure the conservation of cartographic heritage through digitization' belonging to general objective $n^{\circ} 2$, one of the indicators is 'scan rate of old maps in the territory'.

\section{Charters}

The status of charters belongs to the soft law category and they are considered as a very good instrument to manage the relations between public services and staff or service users. Charters have been more and more developed since the 1990's. These agreements present the characteristic to be collective writings entrusted to committees composed of representatives of all the people concerned by the subjects: executives, employees, unions, service users, e.g.: citizens, students... They contain rights guaranteed for the people concerned by the subject sometimes in exchange for the respect of certain obligations.

Charters can be found about general subjects as the 'référentiel Marianne' which was issued in 2005 and updated in 2013 dealing with welcoming the users of all the public services. Set up with users' representatives, this text aims to guarantee quality of care in all its forms: physical, telephone, e mail) and to promote values such as courtesy, accessibility, timeliness, attentiveness, intelligibility, rigor and transparency. It aims to make the quality of reception a shared challenge for all services.

It contains 19 commitments obeying five principles: adapted schedules; friendly welcome; clear information; guaranteed deadlines; continuous listening.

To assess the respect of this charter all over the government services, an external agency evaluates the services by the method of mystery shopping, in a sample of nearly 600 sites. The investigator conducts anonymously by acting as an ordinary user.

Charters can be also found within different public bodies to rule certain processes: promotion of equality between men and women, fight against discriminations, time management, staff mobility.

To illustrate this form of charter, the example of a text concerning staff mobility in the ministries of economy and finances can be given. This chart was discussed with unions' representatives in 2009. This text aims to promote mobility and help the staff at any step of the process. For instance it states that each employee has the right to change his position and to be accompanied by the human resource bureau in his move but he (she) has to occupy a position for a certain duration before moving; however the changing of his (her) position is compulsory in case of promotion. Human resource directorate and unions are regularly controlling the respect of this chart

\section{CONCLUSION, RECOMMENDATIONS}

Though as it has been shown France mainly remains a hard law country, due to its culture and traditions, important evolutions during the last decades have changed public service running 
by introducing new rules related to soft law mainly in its relationships with civil servants.

In order to improve public efficiency in a context of administrative simplification it would be pertinent that in the future this movement would be accentuated particularly concerning external service users with a correlatively diminution of laws, decrees and other regulations, consequently with the reduction of the length of the main codes. This recommendation meets the 'Conseil d'Etat' position which considers that soft law if well used will contribute to the simplification policy of standards and the improvement of the quality of regulations. This simplification has been engaged for these last years, particularly concerning the functioning of companies, and to some extent legal texts ruling work relations between employers and employees or regulated professions. Even if some people there are frightened of what they call 'deregulation', soft law 'à la française', with more relationships ruled by contracts inside lawful frames, could add value to the image of France as a modern state.

\section{References}

Conseil d'Etat: 'Etude annuelle 2013. Le droit souple'. www.conseil-etat.fr/etude-annuelle-2013-le-droit-souple

Arrêté du 30 septembre 2011 relatif à la qualité nutritionnelle des repas servis dans le cadre de la restauration scolaire. www.legifrance.gouv.fr

Weforum: 'The global competitiveness 2014-2015' www.reports.weforum.org/global-competitiveness-report2014-2015

Alain Lambert and Jean-Claude Boulard 'Rapport de la mission de lute contre l'inflation normative' www.ladocumentationfrancaise.fr

'Circulaire sur le renouveau du service public' www.vie-publique.fr/documents-vp/circulaire-23021989-pdf

'Protocole d'accord sur la prévention des risques professionnels dans la fonction publique' www.fonctionpublique.fr

‘Contrat quinquennal de l’UPEC' www.u-pec.fr

'Contrat d'objectifs et de performance de l'Institut géographique national' www.ign.fr

‘Référentiel Marianne’ www.modernisation.gouv.fr 